\title{
IMPORTANCE OF BIOPSIES AND HISTOLOGICAL EVALUATION IN PATIENTS WITH CHRONIC DIARRHEA AND NORMAL COLONOSCOPIES
}

\author{
Importância das biópsias seriadas e avaliação histológica em pacientes com diarreia crônica e colonoscopia normal
}

Franciane Mayra Nicoli KAGUEYAMA, Fernanda Michely NICOLI, Mauro Willemann BONATTO, Ivan Roberto Bonotto ORSO

From the Gastroclínica Cascavel, Cascavel, PR, Brazil.
ABSTRACT - Background: In patients with chronic diarrhea, colonoscopy may identify inflammatory causes or some occult disease, and also can show a normal mucosa. Serial biopsies of intestinal mucosa can be useful for a differential diagnosis, and to modify the treatment. Aim: To evaluate whether the biopsies performed in patients with chronic diarrhea and a normal colonoscopy contribute to the differential diagnosis and alter the therapeutic approach. Methods: A descriptive, retrospective and cross-sectional study using a computerized database was done. Patients with chronic diarrhea and a normal colonoscopy underwent serial biopsies of the terminal ileum, ascending colon and rectum. Results: From 398 records, 214 were excluded. Of the 184 patients enrolled, 91 showed histological changes: $40 \%$ nonspecific inflammation; $5.18 \%$ lymphocytic inflammation, $10.37 \%$ eosinophilic inflammation; $39.26 \%$ lymphoid hyperplasia; $2.22 \%$ collagenous colitis; $2.22 \%$ melanosis; and $0.74 \%$ pseudomelanose. The sites with the largest number of changes were the terminal ileum and right colon. Conclusions: Serial biopsies in patients with chronic diarrhea and normal colonoscopy identified changes in almost $50 \%$ of cases and $22 \%$ of these cases may had modified the treatment after identification of collagenous, lymphocytic and eosinophilic colitis.
HEADINGS - Colonoscopy. Biopsy. Collagenous colitis.
RESUMO - Racional: Nos pacientes com diarreia crônica, a colonoscopia pode identificar causas inflamatórias ou alguma doença oculta, e também evidenciar mucosa normal. Nesse contexto, a biópsia seriada da mucosa intestinal pode ser útil para diagnóstico diferencial e até modificar o tratamento. Objetivo: Avaliar se as biópsias seriadas executadas em pacientes com diarreia crônica e colonoscopia normal contribuem para o diagnóstico diferencial e alteram a conduta terapêutica. Método: Estudo descritivo, retrospectivo e transversal, utilizando banco de dados informatizado. Foram incluídos pacientes com diarreia crônica e colonoscopia normal submetidos à biópsia seriada de íleo terminal, cólon ascendente e reto. Resultados: Foram analisados 398 prontuários dos quais 214 foram excluídos. Dos 184 dos incluídos, 91 apresentaram alterações histológicas: inflamação inespecífica 54 (40\%); inflamação linfocítica sete (5,18\%); inflamação eosinofílica 14 (10,37\%); hiperplasia linfoide $53(39,26 \%)$; colite colagenosa três $(2,22 \%)$; melanose três $(2,22 \%)$; e pseudomelanose um $(0,74 \%)$. Os locais com o maior número de alterações foram o íleo terminal e o cólon direito. Conclusões: Biópsias seriadas em pacientes com diarreia crônica e colonoscopia normal identificaram alterações em quase $50 \%$ dos casos, sendo que $22 \%$ poderiam ter o tratamento modificado após a identificação de colite colagenosa, linfocítica ou eosinofílica.
DESCRTORES - Colonoscopia. Biópsia. Colite colagenosa.

\section{INTRODUCTION}

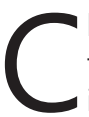
hronic diarrhea may be defined as changes in intestinal transit lasting four or more weeks characterized by reduced stool consistency, increased daily evacuation frequency and a daily stool weight of $>200$ g. The cause may be infectious, endocrine-metabolic, neoplastic, functional or drug related ${ }^{1,6,24}$. Thus, the diagnosis of chronic diarrhea is ample and complex ${ }^{24}$.

Since 1970, colonoscopy has been used to evaluate the large bowel and to

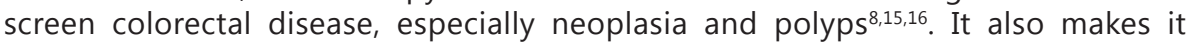
possible to identify early lesions in risk groups, to investigate signs and symptoms of abdominal pain, gastrointestinal bleeding, changes in bowel habits, chronic diarrhea, unexplained refractory iron deficiency anemia and abdominal masses, to follow patients treated for colorectal cancer or inflammatory bowel disease ${ }^{7,13}$. Through colonoscopy, it is possible to visualize the mucosa of the terminal ileum, colon and rectum, and to check for macroscopic lesions ${ }^{3,8,17}$. In addition, several procedures can be performed, especially biopsies ${ }^{2,9,27}$. The introduction of associated technologies, such as chromoscopy and image magnification, has extended the use colonoscopy, making it easier to identify subtle lesions and benefiting a greater number of patients 18,22 . In fact, colonoscopy is currently one of the most complete tools for colorectal disease investigation ${ }^{18,19,22}$.

However, some patients with chronic diarrhea present a normal mucosa on colonoscopy. In such cases, serial biopsies can provide the information required to 
establish a diagnosis and prescribe adequate treatment ${ }^{10}$. Serial biopsies are widely used to diagnose and investigate inflammatory bowel disease and consist of multiple mucosa specimens taken along the colon, from the proximal to the distal part. A complete colonoscopy may include biopsies of the terminal ileum, cecum, ascendending colon, hepatic flexure, transverse colon, splenic flexure, descending colon, sigmoid colon and rectum ${ }^{4,5,26}$. Based on the collected specimens, the pathologist can determine the distribution, extension and depth of the disease and identify changes undetectable on colonoscopy ${ }^{12,25}$.

According to the Royal College of Pathologists (2005), the histopathological findings of endoscopy and colon biopsies only have predictive and clinical value in patients with a clinical picture of persistent diarrhea without bleeding. The guidelines set forth the Quality and Safety Indicators for Endoscopy (2007), issued by the British Society of Gastroenterology in association with the Joint Advisory Group in Gastrointestinal Endoscopy, recommend performing biopsies in all patients with persistent diarrhea ${ }^{5,29}$.

The purpose of this study was therefore to evaluate whether serial biopsies in patients with chronic diarrhea and normal colonoscopy findings contribute to the differential diagnosis and management of chronic diarrhea.

\section{METHODS}

The study protocol was approved by the Research Ethics Committee of Faculdade Assis Gurgacz and filed under \# 209/2013 - CEP/FAG.

The study was descriptive, retrospective and crosssectional. Information was retrieved from digital clinical records at Gastroclínica de Cascavel (Cascavel, Paraná, Brazil) covering the period January 2007 to February 2013. The subjects were patients with chronic diarrhea and normal colonoscopy findings submitted to serial biopsy of the terminal ileum, ascending colon and rectosigmoid colon. The inclusion criteria were diarrhea for over 15 days and normal mucosa without macroscopic changes on colonoscopy. Patients diagnosed with HIV, lactose intolerance, celiac disease, inflammatory bowel disease or diverticular disease and associated complications were excluded, as were patients with incomplete data. The study parameters included age, gender, indication for colonoscopy, duration of diarrhea, colonoscopy findings and histology findings. Lesions were classified by pathologists in accordance with the Atlas of Nontumor Pathology - Gastrointestinal Diseases (2007): 1) lymphocytic colitis or inflammation: increased number of intraepithelial lymphocytes in surface epithelium - at least 20 lymphocytes per 100 epithelial cells (average: 25-32); 2) collagenous colitis: chronic inflammation of the mucosa associated with subepithelial fibrous layer measuring over $10 \mu \mathrm{m}$ and involving capillaries, red blood cells and inflammatory cells; 3) non-specific inflammation: not matching the criteria for specific inflammation but exceeding the limits of the normal mucosa or reactional; 4) lymphoid hyperplasia: mucosa containing activated lymphoid follicles with enlarged germinal center; 5) melanosis and pseudomelanosis: presence lipofuscin pigments in macrophages in the large bowel associated with the use of anthraquinone-based laxatives; 6) eosinophilic colitis: increase of 20 eosinophils per field, compromising the submucosa and muscularis propria.

The collected data were submitted to descriptive statistical analysis.
RESULTS

The clinical records included 398 patients with chronic diarrhea, 184 (46.23\%) of whom met the inclusion criteria: diarrhea lasting over 15 days, no macroscopic changes in the mucosa on colonoscopy, and availability of results of serial biopsy of the terminal ileum, ascending colon and rectosigmoid colon. The female gender was predominant (females $n=122 ; 66.30 \%$; average age: $38.40 \pm 14.72$ years vs. males $n=62 ; 33.70 \%$; average age: $39.16 \pm 14.65$ years).

Thirty-four male patients $(54.83 \%)$ displayed nonspecific inflammatory changes on histology, especially in specimens from the ascending colon. Fifty-seven female patients (46.72\%) presented lymphoid hyperplasia, especially in the terminal ileum.

Histological changes were observed in approximately half the patients $(91 / 184 ; 49.45 \%)$. When classified according to duration of diarrhea, symptoms lasted for 15-30 days in 17 patients (17/184; 9.24\%), eight of whom (8/17; 47.05\%) presented changes on biopsy. The group with diarrhea lasting between 30 days and one year included 85 patients (85/184; $46.20 \%), 47$ of whom (47/85; $55.30 \%)$ displayed histological changes. Likewise, changes were observed in $36(36 / 82$; $43.90 \%)$ of the $82(82 / 184 ; 44.57 \%)$ patients who reported diarrhea lasting over one year (Figure 1).

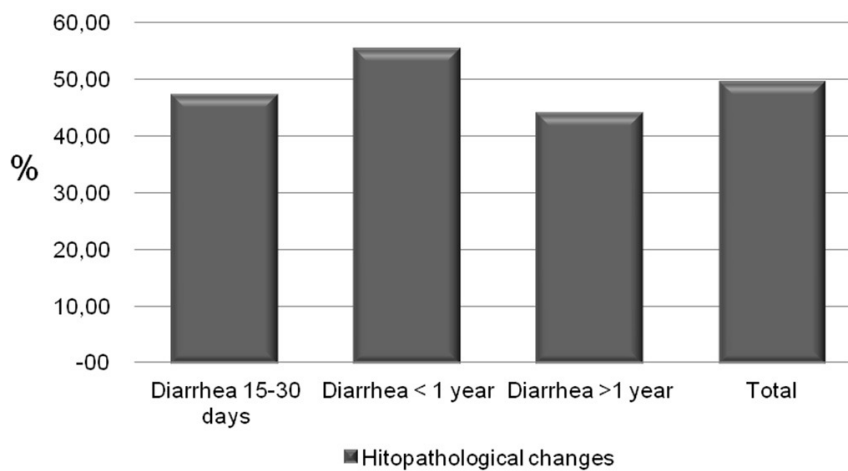

FIGURE 1 - Incidence of histological changes in serial biopsies of the terminal ileum, ascending colon and rectosigmoid colon of 184 Brazilian patients with chronic diarrhea classified according to duration of symptoms

The 91 patients with positive biopsies had a total of 135 changes (with each colon segment considered in separate) distributed as follows: non-specific inflammation $n=54$ (40\%), lymphocytic inflammation $n=7$ (5.18\%), eosinophilic inflammation $n=14(10.37 \%)$, lymphoid hyperplasia $n=53$ (39.26\%), collagenous colitis $n=3(2.22 \%)$, melanosis $n=3$ (2.22\%), and pseudomelanosis $n=1(0.74 \%)$ (Figure 2). Some patients had changes in more than one segment.

Six patients $(6 / 91 ; 6.6 \%)$ had changes in all three segments (the terminal ileum, ascending colon and rectosigmoid colon). Among these, the most frequently observed was non-specific inflammation (4/91; 4.4\%). Twenty-three patients (23/91; $25.27 \%$ ) had changes in the terminal ileum and the ascending colon; non-specific inflammation was again the most frequently observed (10/91; 11\%). Seven patients $(7 / 91 ; 7.7 \%)$ displayed changes in the ascending colon and the rectosigmoid colon; in this group, lymphoid hyperplasia was the most frequent (4/91; 4.4\%). Twenty-nine patients $(29 / 91 ; 31.87 \%)$ presented changes in the terminal ileum only, with lymphoid hyperplasia as the most common (15/91; 16.48\%). Twenty-two patients $(22 / 91 ; 24.17 \%)$ had lesions in the ascending colon only, predominantly lymphoid hyperplasia (14/91; 15.38\%). Two patients $(2 / 91 ; 2.2 \%)$ had lesions (lymphoid hyperplasia) in the rectosigmoid colon only (Table 1 ). 
TABLE 1 - Number of histological changes observed in serial biopsies of the terminal ileum, ascending colon and rectosigmoid colon of 91 Brazilian patients with chronic diarrhea according to affected colon segment and the most frequent type of lesion

\begin{tabular}{|c|c|c|c|}
\hline Affected segment & $\begin{array}{c}\text { Number } \\
\text { of patients }\end{array}$ & $\begin{array}{c}\text { Most frequent } \\
\text { lesion }\end{array}$ & $\begin{array}{c}\text { Number } \\
\text { of patients }\end{array}$ \\
\hline $\begin{array}{c}\text { Terminal ileum, ascending } \\
\text { colon and rectosigmoid colon }\end{array}$ & 6 & $\begin{array}{c}\text { Non-specific } \\
\text { inflammation }\end{array}$ & 4 \\
\hline $\begin{array}{c}\text { Terminal ileum and } \\
\text { ascending colon }\end{array}$ & 23 & $\begin{array}{c}\text { Non-specific } \\
\text { inflammation }\end{array}$ & 10 \\
\hline $\begin{array}{c}\text { Ascending colon and } \\
\text { rectosigmoid colon }\end{array}$ & 7 & $\begin{array}{c}\text { Lymphoid } \\
\text { hyperplasia }\end{array}$ & 4 \\
\hline Terminal ileum & 29 & $\begin{array}{c}\text { Lymphoid } \\
\text { hyperplasia }\end{array}$ & 15 \\
\hline Ascending colon & 22 & $\begin{array}{c}\text { Lymphoid } \\
\text { hyperplasia }\end{array}$ & 14 \\
\hline Rectosigmoid colon & 2 & $\begin{array}{c}\text { Lymphoid } \\
\text { hyperplasia }\end{array}$ & 2 \\
\hline
\end{tabular}

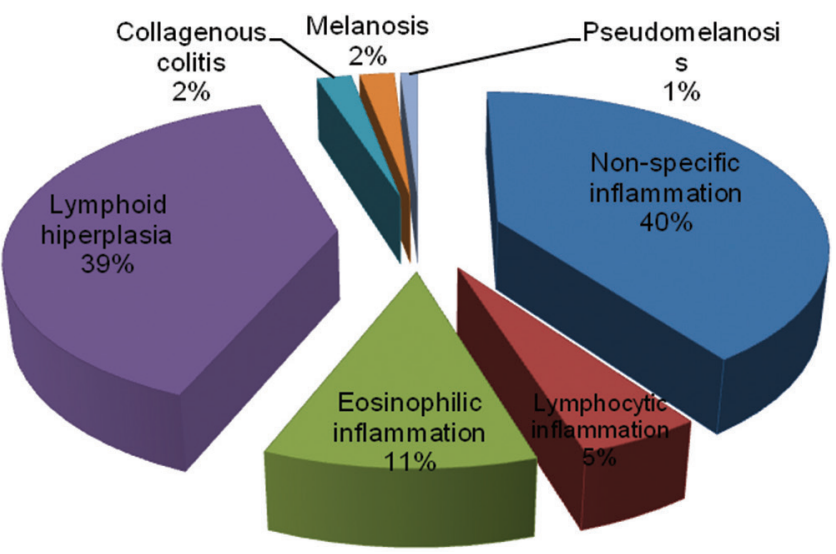

FIGURE 2 - Approximate percentage distribution of anatomopathological changes observed in serial biopsies of the terminal ileum, ascending colon and rectosigmoid colon of 91 Brazilian patients with chronic diarrhea based on the classification provided in the Atlas of Nontumor Pathology (AFIP), 2007

Three other anatomopathological changes were observed: two cases of melanosis (one isolated and one associated) and one case of isolated pseudomelanosis.

As shown in Figure 3, the segments on the right side (the terminal ileum and the ascending colon) were much more frequently affected than the rectosigmoid colon.

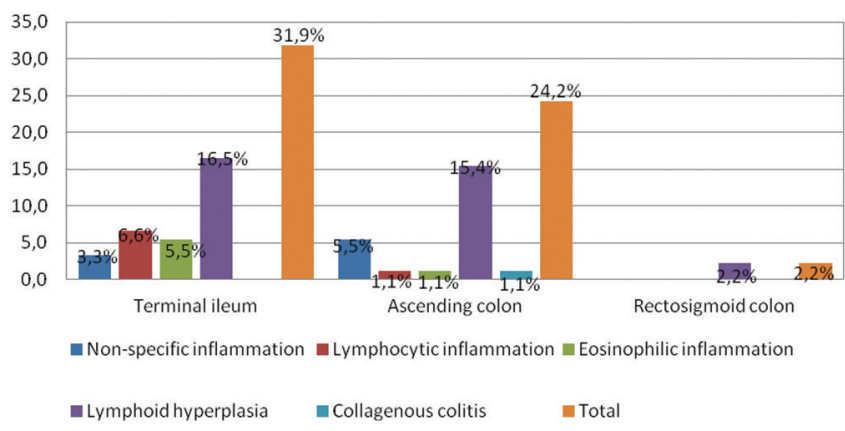

FIGURE 3 - Percentage distribution of anatomopathological changes observed in serial biopsies of the terminal ileum, ascending colon and rectosigmoid colon of 91 Brazilian patients with chronic diarrhea based on the classification provided in the Atlas of Nontumor Pathology (AFIP), 2007, according to affected colon segment

\section{DISCUSSION}

Despite the normal endoscopic appearance of the terminal ileum, ascending colon and rectosigmoid colon in this sample of patients with chronic diarrhea, almost half the collected biopsies (49.5\%) revealed histopathological changes. This matches the findings of Silva et al. (2006) who in addition concluded that the observed changes had diagnostic implications for $32.1 \%$ of their patients. In contrast, Rafi et al. (2008) found serial biopsy of the colon in patients with normal colonoscopy to be of little diagnostic value.

Some of the lesions in this sample may be included in the diagnosis of microscopic colitis, a common finding in chronic diarrhea with increasing incidence over the past 20 years. The condition is currently divided into two major subtypes: collagenous and lymphocytic. The former is a chronic inflammation of the mucosa and a large part of the subepithelium. The latter is a chronic inflammation of the mucosa without subepithelial involvement ${ }^{14,23}$

Eosinophilic colitis may be primary (idiopathic) or secondary to comorbidities. The former is diagnosed by ruling out comorbidities capable of inducing the latter. On endoscopy, mild inflammatory changes with edema, erythema and loss of vascular patterns may be observed. Colon biopsies usually reveal eosinophilic infiltration of the lamina propria extending towards the lamina muscularis mucosae and the submucosa. Healthy bowels have 5-35 eosinophils per high-power field, with greater numbers in the right colon. However, there is currently no consensus regarding the number of eosinophils required to confirm diagnosis, which still requires the presence of excessive infiltration in more than one colon segment ${ }^{30}$. The lack of clear criteria can lead to underestimation of the incidence. Thus, because diagnosis depends on the subjective judgment of the pathologist, the actual number of patients in this sample with eosinophilic colitis may have been higher.

In the present study, serial biopsy made it possible to identify histopathological changes in nearly $50 \%$ of a sample of patients with chronic diarrhea and normal colonoscopy findings. Approximately $20 \%$ of these could be prescribed a more appropriate treatment based on the finding of collagenous, lymphocytic or eosinophilic colitis.

Microcolitis (collagenous or lymphocytic) may be treated with corticoids. The best response is obtained with budesonide, but recurrence is common. The issue is controversial, with some researchers questioning the benefits of treatments which are effective during administration, but not curative. The treatment of eosinophilic colitis depends on the etiology ${ }^{14,23,30}$. Identifying the underlying disease responsible for the signs and symptoms makes it possible to prescribe specific treatment and obtain a positive response ${ }^{23,30}$.

The terminal ileum was the colon segment with the greatest number of lesions observed, possibly due to the presence in this segment of toxins of bacterial, viral and parasitic origin associated with digestion. Lymphoid tissue is normally present in healthy bowels ${ }^{4,11,12}$, but an increased number of lymphoid cells per field suggests changes have occurred. The most frequently observed change was lymphoid hyperplasia, matching the findings of Koksal et al. (2014). The ascending colon presented the secondgreatest number of histopathological changes, indicating that biopsies should focus on the ascending colon and the terminal ileum.

Specimens from patients with diarrhea lasting 15-30 days displayed a high percentage of histopathological changes (47.05\%), suggesting that biopsies taken in this period can yield significant results. According to Rafi et 
al. (2008), colonoscopy is only useful in the diagnosis of patients with diarrhea for over four weeks and/or associated with blood in the stools. Fine and Schiller (1999) believe serial biopsy helps establish a histopathological diagnosis in $15 \%$ of patients with diarrhea lasting over four weeks.

\section{CONCLUSION}

Changes were identified by serial biopsy in almost $50 \%$ of a sample of patients with chronic diarrhea and normal colonoscopy findings. Based on histopathological findings, approximately $20 \%$ could be prescribed a more appropriate treatment. Changes were observed most frequently in the ascending colon and the terminal ileum, suggesting serial biopsies be focused on these segments. Patients with diarrhea lasting 15-30 days displayed a high incidence of changes on histology; therefore, serial biopsy would seem indicated in this patient population.

\section{REFERENCES}

1. American Gastroenterological Association Medical Position Statement. Guidelines for the evaluation and management of chronic diarrhea. Gastroenterology. 1999; 6: 146-1463.

2. Batista RR, Lima RFC, Fonseca MFM, Todinov LR, Formiga GJS Indicações de colonoscopia versus achado de pólipos e neoplasias colorretais. Rev. Bras. de Coloproc. 2011; 31(1): 64-70.

3. Bowles CJ, Leicester R, Romaya C, Swarbrick E, Williams $C B$, Epstein O. A prospective study of colonoscopy practice in the UK today: are we adequately prepared for national colorectal cancer screening tomorrow? Gut. 2004; 53: 277-83.

4. Cuvelier C, Demetter P, Mielants H, Veys EM, De Vos M. Interpretation of ileal biopsies: morphological features in normal and diseased mucosa. Histopathology. 2001; Janeiro; 38(1): 1-12.

5. Elliot VJ, Bateman AC, Green B. The Endoscopically Normal Colon When Is Mapping Biopsy Histopathologically Justifiable? Frontline Gastroenterol. 2012; 3(2): 104-108.

6. Ferreira S, Magalhães $M$, Cotrim I, Pereira A, Saraiva R. Diarreia crónica. J. Port. Gastrenterol. Lisboa, Maio. 2012; 19(3).

7. Fine $K D$, Schiller LR. AGA technical review on the evaluation and management of chronic diarrhea. Gastroenterology. 1999; 116: 1464

8. Finlay AM, Prithi B. Colonoscopy and biopsy. Gastroenterology. 1997; March; 11(1): 65- 82.

9. GUIDELINE: Appropriate use of gastrointestinal endoscopy. American Society for Gastrointestinal Endoscopy (ASGE). Gastrointest. Endosc. 2012; 75(6): 1127-1131.

10. Howat A, Boyd K, Douce G. Histopathology and cytopathology of limited or no clinical value. The Royal College of Pathologists. 2 edicion. 2005; London: RCPath.

11. Koksal AR, Boga S, Alkim H, Ergun M, Bayram M, Sakiz D. How does a biopsy of endoscopically normal terminal ileum contribute to the diagnosis? Which patients should undergo biopsy? [série online] Libyan Journal of Medicine 2014; 9: 23441. Disponível em: http://dx.doi.org/10.3402/ljm.v9.23441

12. Melo MMC, Cury PM, Ronch LS, Gonçalves-Filho FA, Cunrath GS, Netinho JG. Íleo terminal de pacientes submetidos à colonoscopia: aspectos endoscópicos, histológicos e clínicos Arq. Gastroenterol. São Paulo, Abril/Junho. 2009; 46(2).
13. Melo MMC, Netinho JG. Aspectos endoscópicos no diagnóstico de doenças que acometem o íleo terminal. Rev. Col. Bras. Cir. 2010; 37(3): 234-239

14. Münch A, Langner C. Microscopic Colitis: Clinical and Pathologic Perspectives. Division of Gastroenterology and Hepatology, Department of Clinical and Experimental Medicine, Faculty of Health Science, Linköpings University, Linköping, Sweden; and Institute of Pathology, Medical University of Graz, Graz, Austria. 2014.

15. Nagasako $K$, Endo M, Takemoto T, Kmura K, Kondo T. The insertion of fibercolonoscope into the cecum and direct observation of the ileocecal valve. Endoscopy. 1970; 2(2): 123-6.

16. Nagasako K, Yazawa C, Takemoto, T. Observation of the terminal ileum. Endoscopy. 1971; 3(1): 45-51.

17. Nahas SC, Alves PA, Nahas OS, Habr-Gama A, Pinotti HW. Colonoscopia como método diagnóstico e terapêutico na doença do intestino grosso no Hospital das Clínicas da Faculdade de Medicina da Universidade de São Paulo. Rev. Bras. Coloproctologia. 1989; 9 (suppl. 1): 20

18. Nahas SC, Alves PRA, Araújo SEA, Sousa JAHS, Sobrado JCW, Nahas CSR, et al. Emprego da colonoscopia como método diagnóstico e terapêutico das doenças do intestino grosso. Resultados observados em 1.715 exames. Revista Hospital Clínicas Faculdade Medicina São Paulo. 1998; 53: 117-121.

19. Nahas SC, Oliveira FDES, Araújo SE, Lourenção JL, Sobrado JCW, Nahas CSR, et al. Colonoscopia: indicações, contraindicações e complicações. Revista Hospital Clínicas Faculdade Medicina São Paulo. 1998; 53 (1): 91-99.

20. Nahas SC, Marques CFS, Araújo AS, Aisaka AA, Nahas CSR, Pinto $\mathrm{RA}$, et al. Colonoscopia como método diagnóstico e terapêutico das moléstias do intestino grosso: análise de 2567 exames. Arq. Gastroenterol. 2005; 42: 77-82.

21. Noffsinger A, Fenoglio-Preiser CM, Maru D, Gilinisky N. Gastrointestinal Diseases, AFIP Atlas of Nontumor Pathology. First Series, 2007; 5: 656-658.

22. Nossa FLC, Paula NBLBB, Todinov LR, Barreto NPF, Silva JH, Formiga GJS. Colonoscopia diagnóstica e terapêutica. Avaliação das indicações e resultados. Revista Brasileira de Coloproctologia, 1999; 19: 168-171

23. Ozdil K, Sahin A, Calhan T, Kahraman R, Nigdelioglu A, Akyuz $\mathrm{U}$, Sokmen HM. "The Frequency of Microscopic and Focal Active Colitis in Patients With Irritable Bowel Syndrome". BMC Gastroenteroly. 2011; 11 (96).

24. Rafi UD, Manzar Z, Mujeeb-Ur-Rehman AB. Chronic Diarrhea: Large Gut Causes. Professional Med J Dec 2008; 15(4): 479-485.

25. Santos CHMD, Cury MDS, Saad FT. Principais Achados de Colonoscopias Realizadas em Caráter de Urgência e Eletivas. Revista Brasileira de Coloproctologia, 2009; 29(1): 83-87.

26. Santos JCMJ. Preparo do intestino grosso para a colonoscopia - usos, abusos e ideias controversas. Revista Brasileira de Coloproctologia. Rio de Janeiro, Julho/Setembro. 2010; 30(3).

27. Silva EJ, Câmara MAR, Gaidão E, Almeida EC. Colonoscopia: Análise crítica de sua indicação. Rev. Bras. de Coloproc., 2003; 23 (2): 77-81.

28. Silva JG, Brito T, Cintra DAO, Laudanna AA, SIPAHI AM. Histologic study of colonic mucosa in patients with chronic diarrhea and normal colonoscopic findings. J Clin Gastroenteroly, 2006; 40: 44-48.

29. Valori R, Barton RBSG. Quality and Safety Indicators for Endoscopy. [série online] London: British Society of Gastroenterology Endoscopy Committee, 2007. Disponível em: http://www.bsg.org. uk/attachments/170_bsg_grs_indic 07.pdf

30. Yen EF, Pardi DS. Non-IBD colitides (eosinophilic, microscopic). Best Practice \& Research Clinical Gastroenterology. Chicago, USA, 2012; 26: 611-622. 